\title{
Identity and Belonging: Insider/Outsider in Ed Husain's The Islamist
}

\author{
Jillian Curra
}

\begin{abstract}
Since the events of 9/11 and the so-called "war on terror", "Muslim" has been used synonymously with "terrorist" dividing particularly those Muslims living in the West into either "good" Muslims or "bad" Muslims. Ed Husain in his memoir The Islamist uses this dichotomy as well as that of the "witness" in presenting himself as a credible analyst in answering why some young Muslims become attracted to fundamentalist Islamist groups hostile to the West. Ed Husain is a second generation of British Asian Muslim who rejected the Sufi political quietism of his parents for the revolutionary ideologies of Islamic "ideologues" such as Abul A'la Maududi, Sayyid Qutb, and particularly Taqi al-Din al-Nabhani, joining Hizb-ut-Tahrir as an active member. Ed Husain's story is one of a fractured past, manhood, the search for an authentic Islam, and becoming British.
\end{abstract}

\section{Keywords}

Authenticity, identity, Islamist, belonging, "front organisations"

Ed Husain is just one of a growing number of young British Asians who have flirted with Islamic extremism, reformed, and then written a memoir of their experiences. From the beginning, Ed Husain positions himself firmly within a Western democratic/secular discourse, at the same time, professing zealous commitment to the various "Islamist" groups he joins, falls out with, joining yet another even more radical one until a non-Muslim student is murdered by members of the group Hizb-ut-Tahrir that he is a member of. Behind this outward expression of extremism is a studious, well-adjusted young person trying to "find his way" in a society where he is first introduced to Islamic politics at school by a Christian teacher in the form of the recommended RE (Religious Education) textbook, Islam: Beliefs and Teachings by Ghulam Sarwar who connects to various Islamist groups.

Ed Husain's book is written from the perspective of the once "would-be" extremist who has "seen the light". However, throughout the book, Husain often fuses and blurs the "authorial" self with the "experiencing" self, undermining the credibility of his multi-layered identities and belongings. His narrative appears at times mere political expediency and self-promotion as his analysis of Islamism is problematic. Husain presents radical "Islamism" on one hand, as a highly unified, global movement, but on the other hand, he portrays the various groups as fractionalised as well as dominated by in-fighting.

“Throughout the late 1980's, the East London Mosque had been the site of conflict between the rival factions of the Jamaat-e-Islami in Britain (calling

aUniversity of Western Australia, Australia

\section{Correspondent Author:}

Jillian Curr, 8 Green Lane, Hanwell, W7 2PB, London, England 
themselves Dawatul Islam and Islamic Forum of Europe to conceal their extremist connections)" (Husain 2007: 24).

In disclosing his encounters with the various groups, Ed Husain uses the metaphor of "front organisations" to position himself as "good" Muslim and "them" as "bad" Muslims by undermining the sincerity of the various groups by denigrating them as a "front" for something even more devious. Ed describes Ghulam Sarwar as:

...the brains behind the separation of Muslim children from school assemblies into what we called "Muslim assembly" managed by the Muslim Educational Trust (MET). What seemed like an innocuous body, was, in fact, an organization with an agenda. ... Ostensibly it all seemed harmless, but the personnel all belonged to Jamaat-e-Islami front in Britain. (Husain 2007: 21-22)

Furthermore, Husain seems to lump all groups together "as one global Islamist movement" on the basis of having two sides which "are inseparable".

On one hand, there is an ideological unity underpinning all Islamists everywhere; on the other, there are organizational links, continuities, partnerships, and affiliations that bind all Islamist groups to each other such that, we can speak of an Islamist movement (Mondal 2012: 41).

"...thus, he links the ideas of the Egyptian Sayyid Qutb, writing in the 1950's and 60's, to those of Abul A'la Maududi, who founded the Jamaat-e-Islami (JI) in Northern India in the 1930's, and Hassan al-Banna, who founded the Muslim Brotherhood (MB) in 1928".

However, he places most importance on Taqi Nabhani, the founder of Hizb-ut-Tahrir, considered a rather minor player in the overall gravitas of Islamist movements and thought. For Husain, it was his introduction by a Christian RE teacher to the writings of Ghulam Sarwar who ignited his enthusiasm for radical Islamism.

As Ashuman Mondal pointed out for Ed Husain that all Muslim groups, societies, and organisations were "fronts" for radical Islamism.

"Islamic societies on college and university campuses; Young Muslims Organization UK (YMOUK); the Islamic Society of Britain (ISB) and the Muslim Association of Britain (MAB); the Muslim Council of Britain (MCB); East London Mosque; The Islamic Foundation; and even the Respect Party" (Mondal 2012: 39).

Although it would be true to say that some groups might have hidden their real intentions to avoid surveillance, Husain normalises "fronts", therefore negating non-extremist and/or secular voices.

\section{JOURNEY FROM RADICAL ISLAMISM TO GOOD MUSLIM}

Ed Husain's memoir of growing up in 1990's London tells a story of a young person's journey from obedient son, from a "not particularly wealthy, nor especially poor" (Husain 2007: 8) Muslim family to extremism ("bad" Muslim), to Britishness ("good" Muslim). However, Husain blurs his origins placing him in a position of un-belonging. He describes his father as British Indian and his mother as from East Pakistan (Bangladesh) and "(s)omewhere in my family line there is also Arab ancestry; some say from Yemen and others say the Hijaz..." (Husain 2007: 2). Here, his point is two-fold. On one hand, he wants to disassociate himself from a "Hindu contaminated Islam".

The temper of Indian Islam is, compared with Arab Islam, harsh, neurotic and insecure. Whereas it is incontrovertible that "God speaks Arabic", the language of the Qur'an, the status of Urdu is much more uncertain. The Qur'an, as an "uncreated" part of the godhead, cannot be translated; most Muslims in Britain are required to memorise it in Arabic, a language they barely understand. Urdu and English translations were, until recently, looked upon askance. (Ruthven 1990: 55)

On the other hand, by claiming kinship to the Hijaz, he is also linking himself to the Prophet 
Mohammed, reinforcing his Islamic credibility as well as the emphasizing the fluidity of belonging, in addition to, changing territorial boundaries, alluding to the legacy of colonialism. His family practiced a spiritual form of Islam in which individuals/families attach themselves to following the teachings of a spiritual master (Pir). Husain rebels against his parents labelling them as "partial Muslims". Husain's disassociation from the mystical form of Islam followed by his parents reflected a wider issue of insecurity in that as a non-Arab speaker, the divine language of the Qur'an, his Muslim credentials could be brought into question. Ed Husain like other non-Arabic speakers memorised the Qur'an in a language they did not understand.

His first encounters with Islam are from a family friend and spiritual guide, the "Shaikh from Fultholy, who was a master of five Muslim mystical orders, as well as the founder of over 400 religious seminaries in India and Bangladesh" (Husain 2007: 9). It was he who taught Ed Husain to recite the Qur'an in the "art of Koranic recital" (Husain 2007: 11). Although travelling extensively throughout England with this "Pir" who "read aloud in Urdu and intricate Bengali" to various groups of followers, Husain admits that he "looked on bewildered" (Husain 2007: 10).

However, for Ed Husain, this was another world, one not related to his experiences of growing up in England.

"All this teaching me about mainstream, moderate Muslim ethos rooted not in Britain but in eastern Muslim tradition of seeking guidance and religious advice from an elderly sage" (Husain 2007: 15). However, it was not the "authentic" Islam that Husain longed for, one he would travel to Syria to find, rooted in the language of God, Arabic. Husain's insecurity over the authenticity of his parents' Islam would have been reinforced by the fact that their "Islam of the villages, where the mystical practices of Sufism allowed a good number of Hindu beliefs to undermine the strictness of Islam..." (Ruthven 1990: 59).
Husain's Pir came from the rural region of Sylhet on the India-Bangladeshi border where his father met his mother and where her family comes from (Husain 2007: 9).

At the same time, Husain was growing up, so too was the disintegration of the Soviet Union. He cites the breakup of Yugoslavia and the war in Bosnia as a catalyst for his journey into radical Islam.

Bosnia acted as a catalyst for extremism among large numbers of young Muslims in Britain. The international community said they refused to arm the Bosnian Muslims to prevent the escalation of the conflict. But we knew that there was a conspiracy to reduce the number of Muslims in Europe. (Husain 2007: 91)

True Muslims had been defeated by the imperialist and their agents, the rulers of the Muslim world. We had to regain the upper hand in Muslim countries and reject the culture of the West. (Husain 2007: 49)

Ed Husain initially joins the Young Muslim Organisation (YMO - the youth wing of the Islamic Forum of Europe-formed mainly by Bangladeshi youths in East London during a period of racial attacks in Tower Hamlets), progressing to an even more extremist group, the Hizb-ut-Tahrir. Husain's journey on one level is a search for an "authentic" Islam which goes through various stages; teenage rebellion, to would-be terrorist, to moderate British Muslim, to being totally integrated into a Western democratic society based on individual freedoms, the rule of law, tolerance, and diversity from a marginalised, disaffected youth living on the fringes in a country he did not identify as home nor identify with the traditions or culture of his parents.

But Husain's road to Islamic extremism started even before this as a young boy who did not "fit in". $\mathrm{He}$ explains that at an all boys' school in Stepney Green, he was called "glass man" and "boffin" by the other boys. "I could not relate to the boys and they knew it I didn't fit in" (Husain 2007: 7).

In this school, the students were first generation of Bangladeshis who "sang love songs in Hindi from the 
Bollywood movies", while he was tucked away with his news-watching parents in a Victorian terrace in Limehouse, while the other students "lived in council flats and many were neighbours".

$\mathrm{He}$ is an "insider" but also an "outsider", because on one hand, he is their classmate, but on the other hand, he is an "outsider" as he does not belong to their gangs or class. Here, it is blurred as to whether the Ed Husain as narrator, looking back, places himself as an "outsider" or is the "experiencing self" speaking. This ambiguity as to whether it is the narrating "self" looking back or the experiencing "self" speaking re-occurs throughout the narrative.

"I moved between different circles of 'friends', never quite settling down with any one group" (Husain 2007: 7).

He describes having to choose between the various Asian gangs that the other boys were members of, such as the "Brick Lane Mafia or the rival Canon Street Posse, the Stepney Green Posse or the Bow Massive" (Husain 2007: 7).

"Uncommitted I continued to be a loner at school, occasionally bullied, frequently sworn at, and regularly ignored in most cases" (Husain 2007: 8). Not only does Husain distance himself from the other students, there is an underlying disapproval of their behaviour constituting a sense of superiority in that he was the "good" boy, a position that he would later translate into "good" Muslim. This also reflects Husain's ambivalence around his multi-layered identities and his unease with being associated with his mother's country of origin. It is also ambiguous who is talking here, the reformed narrating "self" or the experiencing "self" and it is this blurring which leaves Husain "unmoored" and "floating" disconnected from the world he lives in.

\section{BELONGING}

According to Ghassan Hage:
An insider is someone who identifies with the "order of things" within a social space or habitus in that they know how things are done around here. The insider is someone who perceives that this collective order of things is their own but as an outsider is someone whose mental and bodily dispositions have evolved somewhere else and thus feels culturally "out of place". (Hage 2006: 342)

Husain as an "insider" is able to understand the socio-cultural space he inhabits, he is familiar with the norms and social behaviour of where he lives and goes to school, in other words, he understands "the order of things", the rules of social discourse. But on the other hand, Husain portrays himself as "out of place" positioning himself as if he "evolved somewhere else" and is therefore "culturally out of place". We see this with the school and the other students, "they" identify with Hindi love songs from Bollywood movies, his parents watch the news; "they" belong to gangs or play football/rugby, he spends his time memorising verses from the Qur'an; "they" smoked cigarettes, grew long hair, and "hung out" after school and at weekends, "they" lived in council flats, he lived in a Victorian terrace. "A key part of my life, from a very young age, had been religion" (Husain 2007: 9). Here, he distances himself from those he believed to be socially "inferior". However, it is ambiguous who is speaking. Is it the "extremist" Husain, the experiencing "self", or the narrating "self"? Obviously, he is speaking from the position of "insider" as he is familiar with the "norms" and "social behaviour". However, positioning himself as the "outsider", he dislocates himself from those he is trying to leave behind. This dislocation pivots him to a "higher status". Ghassen Hage argues that people who are outsiders are not as "valorised" as those "insiders". Here, it is clear that Ed Husain is talking about class. He is not one of those groups who live on the periphery, but by representing those attributes (middle-class British values), he becomes an "insider".

Ghassan Hage believes that the newest communities "are constantly subjected to various 
social forces of inclusion and exclusion that can maintain or transform their status" (Hage 2006: 344).

Husain describes his role in Hizb-ut-Tahrir in London as important, firstly, because "(he) was responsible for the Hizb-ut-Tahrir entering Tower Hamlets College" (Husain 2007: 86). And secondly, "(t)o me, it became crucial that we explain to Muslims at college that they had an important role to play in the world" (Husain 2007: 88).

Husain describes being as a child, being subjected to racist taunts on school trips, but in school, although an "outsider", he does not seem to have been subjected to any form of overt discrimination. For Husain, the attraction of Taqi Nabhani was:

“(T)he concept of the 'Muslim nation', as opposed to a number of disparate ethnic communities, was the key. To the Hizb, Indians, Malaysians, Turks, Indonesians, Arabs, Africans, were all part of a single, global Muslim nation, ummah” (Husain 2007: 90).

Husain's reasoning for his involvement in political Islam was "....around rejecting democracy, removing the rulers of the Muslim world, and the duty of Muslims in the West to help advance the cause of our brothers in Muslim countries..." (Husain 2007: 100). This somehow seems reminiscent of George W. Bush's later pledge to rid the Muslim world of dangerous regimes and leaders as well as, unlike Husain to spread democracy to the world. Both statements have the ring of empire building in addition to placing what comes out of the West to be superior to anywhere else. In other words, Husain's words border on mimicking hegemonic discourses coming from the West.

Husain's disillusionment with these radical Islamist groups came suddenly at a meeting of the Islamic Society when a man Husain describes as someone who later became a councillor for the Respect Party attacked his "presidency". "As I listened I could see how these very individuals I considered to be brothers could in turn nasty, violent even" (Husain 2007: 109).
Husain maintains that his reason for involvement in radical Islamism was because "(he) wanted to be a better Muslim, not in order to divide Muslims. I had served the Islamic Society, raised the profile beyond that of any other college in Britain, in order to make Islam superior, not to instigate infighting" (Husain 2007: 109).

Later in the book, Husain describes himself as "going through a period of transformation" (Husain 2007: 189). He gets a job at HSBC, falls back on the writings of an American, Shaikh Nuh Keller, who likes his parents and their family Pir believing in introspection, and "spiritual enrichment, transmitted from the hearts and mouths of men in an unbroken chain of narration, known as isnad, from early times to the present" (Husain 2007: 189).

This illustrates a constant theme in the book, Husain's search for an "authentic, pure" form of Islam "uncontaminated" by Hinduism and parents' spiritualism to an "uncreated" Islam of God and Arabia - the birthplace of the Prophet Mohammed who is considered the "perfect" person who all Muslims should emulate.

Husain frames all Islamisms together as a homogenous whole failing to identify the differences in the ideologies of the different "ideologues". For example, Abul A'la Maududi who believed that dividing communities into territorially separate nation states was contrary to the political ideal of Islam, being initially opposed to the creation of the separate state of Pakistan during the talks on Indian Independence from Britain, something Husain fails to recognise when he accuses Maududi of a "lack lustre" approach to nation building in Pakistan and inflates the importance and influence of Taqi Nabhani, who believed that the British utilised nationalism to divide the Muslims to make them more vulnerable to European conquest, calling for an Arab polity which would encompass the entire Arab world working for the liberation of Palestine. According to David Commins, Taqi Nabhani was not interested in creating 
an Islamic state nor establishing Islamic law as the basis of a Muslim society something that Ed Husain seemingly fails to recognise, placing doubt on his positioning as a "credible witness" capable of analysing the events in either "selves". In other words, Husain by failing to acknowledge the different ideological differences of Maududi, Nabhani, and Sayid Qutb puts forward question in his position as a "credible witness" in the narration of social "facts" in the form of memoir.

In Husain's "narrating self', looking back on the events, firstly, leads him to become an advocate of radical Islam, and the "experiencing self", seems blurred as it is unclear if, although Husain points to him being a "main player", he was always on the "outside" of these groups "looking in" just like his "choice" to remain "outside" the gang culture at his Stepney Green School.

On one hand, Husain narrates his memoir from the point of view of being an "insider" and therefore, a credible witness to events, but on the other hand, he seems to "float" from "insider" to "outsider", making his position ambivalent and multi-layered as he positions himself as "mediator" among radical Islam, young male Muslims living in the West, and British society in the act of remembering. This is "presented" as the voice of "all" Muslims, consequently, silencing other Muslim voices. Although he highlights the fluidity of belonging, he also does not allow for those moderate Muslim "voices" who did not belong to "front" organisations or extremist groups. Ed Husain presents "all" Muslims as "extremists" by failing to differentiate between the ideologies of the different Islamist "'ideologues", and, ordinary Muslims going about their daily life not having ascribed to the teaching of these "ideologues".

Another theme throughout the book is hybridity, Ed Husain's multi-layered "selves' contest and conflict while he negotiates between his "Britishness" and "Muslimness". Throughout the book, Husain emphasizes his belief in "British values" contrary to his anti-British radical Islamist self. To do this, he frames Muslims using a "good" Muslim/"bad" Muslim dichotomy, but instead of presenting a new way of framing Muslims living in the West, he falls back on a "them" and "us" dichotomy common in media presentations of Muslims, reinforcing the "enemy within" discourse as well as reinforcing the views of certain groups who perceive Muslims as not "fitting in" accepting the British way of life.

I returned to Britain because I believe it to be my home. I want my children to grow up here. I do not want them to consider Islamism an option as I once did. I worry when I see young girls, many below the age of eight, wearing the hijab to primary school. (Husain 2007: 282)

Husain's writing as the narrating "self", in other words, reformed Islamist "insider" and therefore "good" Muslim positions himself as an expert on the dangers of Islamism. However, in utilizing this dichotomy of "good" and "bad" Muslim, he not only promotes but also reinforces media representations of Muslims as the menace from within threatening "Britishness" rather than challenging Western hegemonic discourses that equate the Muslim "other" as "terrorist" or offering alternative voices. $\mathrm{He}$ therefore not only negates the presence of other forms of Islamism that are not anti-Western but also silences their voices "to be heard" by not allowing them to "speak". We only hear the "voice" of Ed Husain, the "insider", a credible witness by virtue of having "reformed" himself within the voices of the dominant Western discourses of "good" and "bad" Muslim.

As the "narrating self", Husain often presents contradictory images of Muslims living in Britain. On one hand, he presents the Muslim communities as law-abiding and integrated, for example, “...(the) silent majority of law-abiding and loyal Muslims who work hard in business and the professions across Britain not seeking to turn religion into politics" (the secular view of separation of religion and politics adhered to in Western democracies), whereas, he had 
previously stated "...the ideology that led to successful suicide bombings of July 7, 2005 and many similar though thwarted attempts since then is still alive and firmly rooted among Britain's young Muslims".

Husain's narration consequently is complicit in perpetuating public discourses of Muslims as "threat/terrorist" although criticising the media and sections of the government of doing just that in perpetuating stories of Muslims failing to integrate and living "parallel lives" using integration or lack of a measuring stick for possible Muslim terrorists.

Nicole Falkenhayner argues that the "fanatic son" trope is not something new and has emerged "fully formed" before $9 / 11$ and 7/7. This was a familiar trope but before the events of $9 / 11$, these characters were nearly always comical, not to be taken seriously, whereas post these events, the "fanatic son" became something more sinister, someone who was dangerous and capable of violent action against the country he was born in like the 7/7 London bombers. Falkenhayner believes that this trope has been made emblematic for conflict in British multicultural society (Falkenhayner 2014: 104).

This is something that Ed Husain would have been aware of when framing himself within this trope as a method of understanding the attraction of extremist forms of Islam for young Muslims growing up in Britain, leading him to ambivalence on his own positioning during this period.

\section{MEMOIRS}

Ashuman Mondal believes that the function "of a memoir is to reflect on the past as well as drawing lessons for the present author and readers" (Mondal 2012: 37). Memoirs can contain messages that are "explicit" and "implicit" as well as being "social and private". As already stated, they also consist of two subjectivities_-“a 'narrating' self which is looking back from the vantage point of the present on an 'experiencing' self' (Mondal 2012: 38). From the perspective of memoir, in terms of representing social "facts", Ed Husain's "narrating" self and "experiencing" self are blurred therefore putting forward question in his positioning as "credible witness" due to the creation of "representational uncertainty" (Mondal 2012: 38) particularly as Husain is writing from the vantage point of the present positioning himself as a "reformed radical Islamist". "As an Islamist I had been passing concepts to undermine the West (now I was) citing universal values of human rights, freedom for women, rights for oppressed minorities of all categories..." (Husain 2007: 228). Husain wants to "unmake" his former self through the text by writing from the inside of political Islam. "This is the story of my journey from the 'inside', in the fullest sense of the world: inside today's Islam, inside Britain's Muslim communities, inside my own heart" (Husain 2007).

In Husain's memoir, the discontinuity between the "present" self is radically different from the one who experienced those things, but Husain often blurs these "selves", creating a representational uncertainty. Husain is metaphorised from a radical Islamic "ideologue" pursuing the downfall of the West replaced with an Islamic Caliphate to a well-adjusted and integrated British citizen expounding the virtues of British democratic values.

Throughout the book, the recurring trope of devotion, firstly to Sufi Pir, then devotion to various Islamist causes portrays Husain as replacing one addiction for another. Therefore, rather than "going through a period of transformation" (Husain 2007: 189), this seemingly insatiable "need" of re-invention through another "cause" and/or devotion puts forward question to his insider's view as credible "witness". Another theme is that he presents "all" Muslim organisations as "fronts" for Islamist radicalism pandering to mainstream discourses which equate Muslim with terrorist, out to destroy the West. His response is to equate "moderate" Islam with a non-political pietism that is radically antithetical to 
Islamism. Husain sees conspirators everywhere and "it is this blanket suspicion of all Muslim efforts to organize politically" where Ed Husain's memoir falls apart in his inability to differentiate between "genuine moderate groups" from "front" organisations (Mondal 2012: 40). It is therefore implicit in Husain's memoirs that he views all Islamisms as a threat to the West.

It is necessary for Husain to link all Islamists together as an "all-embracing ideology" as this mimicks his own vision of:

A global movement that encompasses political parties such as Pakistan's Jamaat-e-Islami and its offshoots (e.g. Young Muslims Organisation UK), the Muslim Brotherhood and its affiliates (HAMAS, Muslim Association of Britain), Hizb-ut-Tahrir and Al-Muhajiroun, the Taliban and beyond them, the militant jihadist organiszations such as al-Qaeda. The basic architecture of Islamism presented by Husain is simple: Muslim politics $=$ Islamism $=$ extremism $=$ terrorism . (Mondal 2012: 43)

Although an insider's account, he blurs the distinction between the "inside" perspective of the experiencing self and the "outside" perspective of the narrating self which in turn blurs the distinction between the Islamists and "ordinary" Muslims. Husain's portrayal of Islamism is that as he graduated from one Islamism to an even more extremist ideology and group so will all other Muslims who see Islamism as an alternative to Western discourses.

Ghassen Hage contends that it is practically the case that in the binary insider/outsider, it is often the insider side of the binary that is more highly valorised than the outsider side. But there is no logical necessity for this. There are desirable modes of being inside and undesirable ones. And the same goes for being an outsider. For example, when there are outsiders that we morally valorise, we are quick to make them insiders. For Husain, being an outsider was an undesirable mode of belonging. By expounding British values, Husain places himself as an insider having returned to Britain from the Middle East. "Just as my Britishness had come to the fore while living in the Muslim world, my Muslimness now seeks expression" (Husain 2007: 268). Through positioning himself as the "good" Muslim, Husain has "earned" his Britishness, his insider status.

Husain is attracted to Islamist groups as he is valorised as an insider. In following his father's Pir for all his hard memorising the Qur'an and having perfect Arabic pronunciation, he remained on the outside as while he sat by the Pir's side, followers came to venerate the Pir while he remained invisible.

"As he approached the departure gates at Heathrow, a crowd of his devotees surrounded him for a last blessing, a touch, a farewell. I kept at a distance, not comfortable with the pushing and shoving" (Husain 2007: 17).

Husain's young life was also portrayed as being invisible whereas his life as an radial Islamist put him in the spotlight.

With his only school friend, another misfit Falik, Islamism gave them an identity that rejected the quietism of their parents' Islamic beliefs and practice. In doing so, they were able to negotiate a place in British society that was visible and active. They believed at the time that radical Islamism would give them a unique voice in a country they felt marginalized and "voiceless".

"Together, we started to assert a new identity: we were young, Muslim, studious, and London born. We were not immigrants and neither understood the mentality of our peers who reminisced about their villages in Bangladesh, nor shared their passion for Bollywood actresses" (Husain 2007: 23).

At the YMO and the Islamic Forum of Europe, Ed Husain was able to emerge from the shadow of his father's world.

There I was a young boy, in my father's shadow; here the place was buzzing with young, trim-bearded, English-speaking activists... everybody here seemed to know their place. 
I was introduced to no fewer than fifteen people... almost without exception they took an interest in me, my studies, my family, and my future plans. (Husain 2007: 27)

\section{CONCLUSIONS}

By writing a memoir from the position of "insider", it was supposedly to give authenticity to the question: Why do young British Muslims become extremists?

However, what Husain does by lumping all Muslim groups into "front organisations" silences any alternative voices. According to Husain, all Muslim groups are Islamic extremists, there are no moderate voices.

By positioning himself as "insider", Husain frames himself as the person who can provide a "truthful" view of events because of his insider knowledge endowing him with the authority of the witness. In other words, he was there, as the "experiencing" self. Therefore his "experiencing" self becomes a testimonial of the "truth" but this breaks down through his depiction of all Muslim groups and organisations as "fronts" for extremism. Consequently, he is transformed by the text into an "unreliable" witness.

The other "trick" the text plays on Husain is his portrayal of "self" as the reformed extremist son who was thrown out of the family home by his pietist parents. His credibility as "witness" is undermined as this trope was already established in fiction writing, that of the "fanatic son".

"Husain laudable aim is trickled by language, the language of tropes; Husain writes his 'Islamist' right into a discourse already established in fictional writing, and uses tropes that these texts have already established" (Falkenhayner 2014: 147).

Husain in the beginning of the book asserts an English persona through a "typical" English childhood, one devoid of discrimination.

My earliest memories are fond recollections of school trips to the green, serene English countryside. I remember the uninhibited joy of walking along the coast in Upnor, being invited abroad, cheerful anglers' small boats, and devouring fish and soggy chips together.

At weekends, she often took us to theatres in the West End. (Husain 2007: 2)

However, this all changed when he started school in East London, a boy's school of students who were mainly Asian. As a consequence, Husain becomes defined in terms of public discourse. And is it this realisation of his "mixed heritage of being British by birth, Asian by descent and Muslim by conviction was set to tear me apart in later life" (Husain 2007: 3)?

Husain's approach of writing as an "insider" equating "witness" with "authenticity" therefore "truth" has pitfalls in essentialising Islamic extremism to one of "front organisations".

"It risks inflating the view from inside whilst, conversely minimizing developments outside" (Mondal 2012: 45).

In addition, it is not clear in his accounts of the various groups he joined, particularly Hizb-ut-Tahrir and Taqi Nabhani, that who was considered a minor player in political Islam, but whose importance Husain has inflated whether he still believes this or only at the time or "whether this is presented as the subjective perspective of the 'experiencing' self of the time, or the presumably more 'objective' vision of the 'narrating' self looking back" is blurred, obfuscating the difference between moderate groups and extremist groups.

Consequently, "it also results in an equivocation that blurs the distinction between the 'inside' perspective of the experiencing self and the 'outside' perspective of the narrating self, which in turn blurs the distinction between Islamists and 'ordinary' Muslims" (Mondal 2012: 45).

Husain's use of the "good" Muslim/"bad" Muslim dichotomy diverts the reader from the real issues for Muslims living in the West. That is, being visible and also active members of the society without being the victims of such accusations as of living "parallel lives" 
and "failing to integrate", therefore supposedly posing a threat to British democracy. Husain fails to provide answers to the challenges faced by ordinary Muslims in reconciling their religious beliefs and traditions with living in a Western secular democracy rather than Muslim majority countries, in other words, how do you live as a minority?

Ashuman Mondal believes that The Islamist presents "a very monochromatic, dualist picture of Muslim life in Britain, which doesn't do justice to the polychromatic, multivalent, contradictory and dynamic texture of Muslim communities in Britain and Europe..." (Mondal 2012: 49-50).

Ed Husain's "addiction" to radical Islamist groups, the sense of "importance", membership bestowed on him, and his eventual reformed "self" into a law-abiding "good citizen" does not necessarily provide the only convincing way forward for Muslims living in the West as it silences other voices and alternative journeys.

\section{References}

Beilharz, P. and T. Hogan, 2006. Sociology: Place, Time and Division. South Melbourne: OUP.

Bourdieu, P. 1984. Distinction. London and New York: Routledge.
Commins, D. 1991. "Taqi Al-Din Al-Nabhani and the Islamic Liberation Party." In The Muslim World, vol. LXXXI, nos. 3-4. Retrieved November 3, 2016 (http://users.dickinson. edu/ commins/TaqiAl-dinAl-Nabhani.pdf).

Falkenhayner, N. 2014. Making the British Muslim: Representations of the Rushdie Affair and Figures of the War-on-Terror Decade. Basingstoke, UK: Palgrave Macmillan.

Hage, G. 2006. "Insiders and Outsiders.” In Sociology: Place, Time and Division, edited by P. Beilharz and T. Hogan. Oxford: Oxford University Press.

Husain, ed. 2007. The Islamist. London \& New York: Penguin Books.

Maynes, M. J., J. L. Pierce, and B. Laslett. 2008. Telling Stories: The Use of Personal Narratives in the Social Sciences and History. Ithaca \& London: Cornell University Press.

Mondal, A. 2012. "Bad Faith: The Construction of Muslim Extremism in Ed Husain's The Islamist." In Culture, Diaspora, and Modernity in Muslim Writing, edited by R. Ahmed, P. Morey, and A. Yaqin. New York \& London: Routledge.

Rahim, S. 2007. "The Islamist by Ed Husain." London Review of Books 29(14):20-22.

Ruthven, M. 1990. A Satanic Affair: Salman Rushdie \& the Rage of Islam. London: Chatto and Windus.

\section{Bio}

Jillian Curr, Ph.D. candidate, University of Western Australia, Perth, Australia; research field: English and cultural studies. 